\title{
Telaprevir-related DRESS syndrome complicating hepatitis C treatment
}

\author{
Süheyla Kömür, Aslıhan Ulu, Behice Kurtaran, Ayşe Seza İnal, Yeşim Taşova, Hasan Salih Zeki Aksu \\ Cukurova University, Infectious Disease Department, Adana, Turkey
}

\begin{abstract}
In chronic hepatitis $C$ patients telaprevir attracts attention with high sustained virologic response and short term treatment however it is associated a new spectrum of adverse events, especially several cutaneous manifestations. We report a 66-year-old female patient developed drug reaction with eosinophilia and systemic symptoms during telaprevir based hepatitis $C$ treatment. All antivirals were discontinued and she was treated with supportive care. Systemic and cutaneous symptoms resolved in follow-up. Although rare, clinicians should be aware of potentially severe cutaneous skin reactions during telaprevir -based therapy. J Microbiol Infect Dis 2015;5(1): 36-37
\end{abstract}

Key words: Eosinophilia, hepatitis C, rash, telaprevir

\section{Hepatit C tedavisinde karşılaşılan telaprevir ilişkili DRESS sendromu}

\section{ÖZET}

Kronik hepatit C tedavisinde telaprevir yüksek kalııı viral yanıt ve kısa süreli tedavi özelliğiyle dikkat çekmektedir, ancak özellikle çeşitli cilt yan etkileri olmak üzere yeni yan etkilerle ilişkilidir. Biz telaprevir bazlı hepatit $C$ tedavisi esnasında sistemik semptomlar ve eozinofilinin eşlik ettiği ilaç reaksiyonu gelişen 66 yaşında bir kadın hasta sunduk. Hastanın tüm antiviralleri kesildi ve destek tedavi verildi. Takibinde sistemik ve cilt bulguları düzeldi. Nadir olmasına rağmen telaprevir bazlı tedavi esnasında ciddi cilt reaksiyonları akılda tutulmalıdır.

Anahtar kelimeler: Döküntü, eozinofili, hepatit C, telaprevir

\section{INTRODUCTION}

In chronic hepatitis C patients telaprevir (TVR) attracts attention with high sustained virological response and short term treatment however it is associated a new spectrum of adverse events. ${ }^{1}$ Several cutaneous manifestations related with TVR have been reported. ${ }^{2}$ We report a 66 -year-old female patient developed drug reaction with eosinophilia and systemic symptoms (DRESS) during TVR based hepatitis $C$ treatment. To our knowledge, our patient is the first reported case with telaprevir-related DRESS from Turkey.

\section{CASE}

A66-year-old female with chronic hepatitis $C$ in week seven of treatment with peginterferon alfa-2a, TVR and ribavirin, presented with generalized pruritic maculopapular eruption involving her trunk, abdomen, arms, face and legs bilaterally (Figure 1). The rash started during $6^{\text {th }}$ week of treatment and subse- quently generalized, involved $>90 \%$ of her body surface area. The physical examination revealed fever, $38.5^{\circ} \mathrm{C}$, and the general especially facial oedema (Figure 2). She had malaise, nausea and vomiting. She was hospitalized. Complete blood count revealed: WBC: $3.5 \mu \mathrm{L}(4.5-10), \mathrm{Hgb}: 8.8 \mathrm{~g} / \mathrm{dL}$, plt: $93 \mu \mathrm{L}$, neutrophil $47 \%$, eosinophil $19.6 \%$ and lymphocytes $27 \%$. Serum biochemical tests were: AST: $85 \mathrm{IU} / \mathrm{L}(0-31)$, ALT: $158 \mathrm{IU} / \mathrm{L}$ (0-41), ALP $255 \mathrm{IU} / \mathrm{L}$ (30-120), BUN: $38 \mathrm{mg} / \mathrm{dL}$ (5-20), creatinine: $1.9 \mathrm{mg} /$ $\mathrm{dL}(0.6-1)$, total $\mathrm{lgE} 1100 \mathrm{IU} / \mathrm{ml}$ (10-180). She was diagnosed DRESS. The antiviral medications were discontinued. She was treated with supportive care and hydration. Systemic antihistamines and topical steroids were started. In three days her fever was under control. Systemic symptoms resolved in ten days. Cutaneous symptoms resolved completely in four weeks subsequent to cessation of therapy. She had achieved rapid virologic response with undetectable virus at $4^{\text {th }}$ week and also follow-up visit in third month HCV-PCR was still undetectable. 


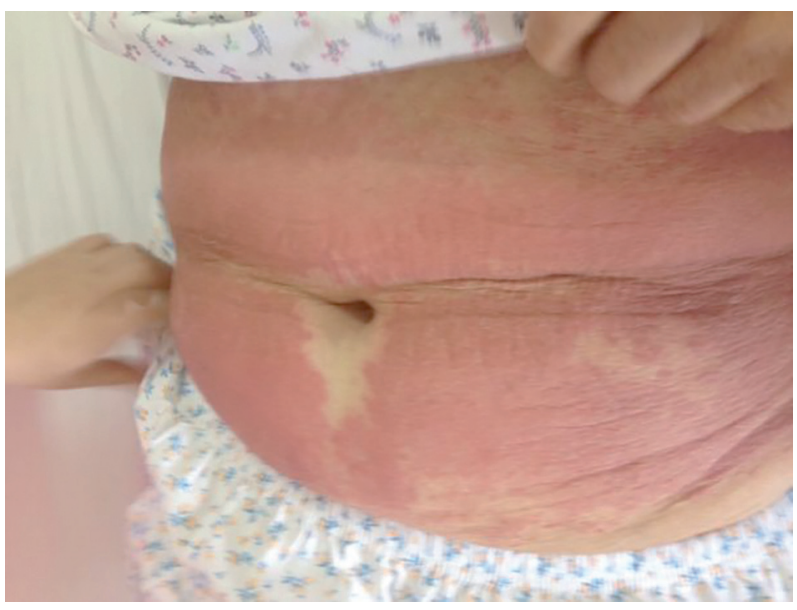

Figure 1. The generalized pruritic maculopapular eruption.

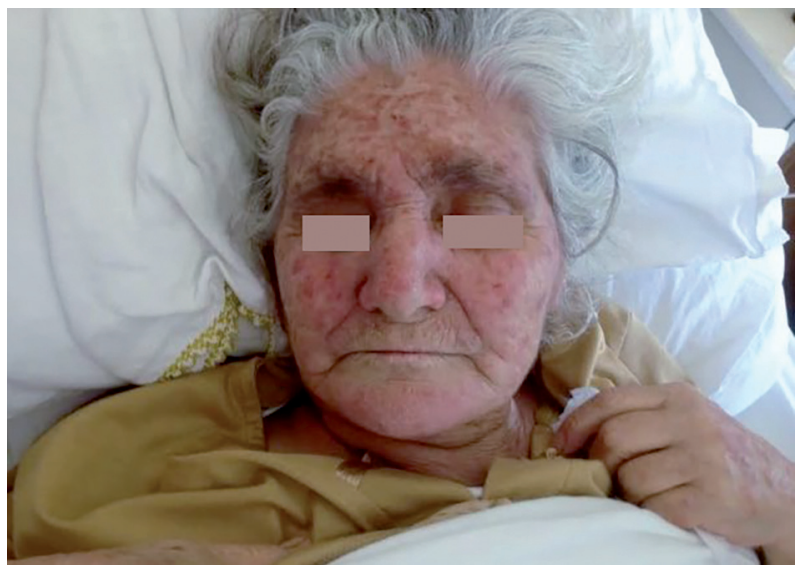

Figure 2. The facial oedema and rash.

\section{DISCUSSION}

TVR has been shown to dramatically improve sustained virologic response however increased serious cutaneous adverse effects have been reported. ${ }^{3}$ Pruritus, eczematous or cutaneous eruption is observed in $56 \%$, besides, severe cutaneous adverse reactions were reported in $3.7 \%$ of patients receiving TVR. In phase II and phase III trials 11 patients $(0.4 \%)$ with DRESS and three patients with suspected Stevens-Johnson syndrome were reported. ${ }^{4,5}$ Rash is most often observed within the first 4 weeks, but can occur at any time. There is no identified predictive factor, and skin reaction mechanism is unknown. ${ }^{2,6}$ Our patient had complaints of pruritus since first weeks of treatment. She had advised to use emollient creams and lipid-rich lotions. However she presented with generalized rash in the seventh week of treatment diagnosed as DRESS. DRESS is a life-threatening condition that is characterized by the clinical triad of fever, rash, and internal organ involvement. The liver is the most frequently involved internal organ. Hypereosinophilia is the third common reported finding in DRESS syndrome. ${ }^{6}$ Our patient admitted with fever and the levels of aspartate aminotransferase and alanine aminotransferase increased by approximately 3-fold above the normal limits, she had $19.6 \%$ eosinophilia.

In the study of Roujeau's et al, the incidence was significantly higher with age above 45 years, body mass index below 30 , white race, and first HCV therapy. ${ }^{7}$ Our patient was elderly and her body index was 27 , but she was receiving therapy for the second time because of relapse.

In telaprevir phase III trials, the rate of discontinuation of antiviral drugs due to skin manifestation was low. In the management of dermatological side effects, education of patient about good skin care practices is important. In case of severe cutaneous reaction, discontinuation is strongly recommended. Cutaneous and systemic symptoms usually improve after discontinuation and support care..$^{3-6}$ Our patient's fever was under control in a few days and skin lesions resolved in four weeks.

In conclusion, although majority of TVP-related cutaneous manifestations is mild or moderate, lifethreatening severe conditions like DRESS should be kept in mind.

\section{Acknowledgement}

This case was presented in the XII.National Viral Hepatit Congress, 2014" as a poster.

\section{REFERENCES}

1. Fontaine $\mathrm{H}$, Pol S. Antiviral activity of telaprevir and boceprevir for the treatment of hepatitis $\mathrm{C}$ virus infection in treatment-experienced patients. Clin Gastroenterol Hepatol 2011;35:S59S63.

2. Picard O, Cacoub P. Dermatological adverse effects during genotype-1 hepatitis $C$ treatment with the protease inhibitors telaprevir and boceprevir. Patient management. Clin Gastroenterol Hepatol 2012;36:437-440.

3. Chopra A, Klein PL, Drinnan T, Lee SS. How to optimize HCV therapy in genotype 1 patients: management of side effects. Liver Int 2013;33 Supp:30-34.

4. Jacobson IM, McHutchison JG, Dusheiko GM, et al. Telaprevir for previously untreated chronic hepatitis $\mathrm{C}$ virus infection. $\mathrm{N}$ Eng J Med 2011;364:2405-2416.

5. Zeuzem S, Andreone P, Pol S, et al. Telaprevir for retreatment of HCV infection. N Eng J Med 2011:364:2417-2428.

6. Cacoub P, Bourliere M, Lübbe J, et al. Dermatological side effects of hepatitis $C$ and its treatment: Patient management in the era of direct-acting antivirals. J Hepatol 2012;56:455-463.

7. Roujeau JC, Mockenhaupt M, Tahan SR, et al. Telaprevir-Related Dermatitis. JAMA Dermatol 2013;149:152-158. 